\title{
Penentuan Kadar Kalium Sorbat dan Persen Recovery pada Selai dengan Metoda High Performance Liquid Chromatography
}

\author{
Pevi Riani ${ }^{1}$, Ulvie Ameinda Fannin ${ }^{1}$ \\ ${ }^{1}$ Politeknik ATI Padang, Bungo Pasang- Tabing, Padang, 25171, Indonesia
}

\section{ARTICLE INFORMATION}

Received: December 04, 2020

Revised: December 17, 2020

Available online: December 31, 2020

\section{KEYWORDS}

Fruit Jam, HPLC, Potassium Sorbate, Preservative

\section{CORRESPONDENCE}

Name: Pevi Riani

E-mail: rianipevi@gmail.com

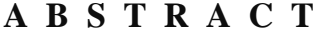

Fruit jam is one of the preserved products that have a soft texture that contains crushed fruit and is mixed with sugar with the addition or without the addition of water. Preservatives are added to prevent damage to jams. A preservative that is usually added to jam is potassium sorbate. Potassium sorbate is commonly used as a preservative because it dissolves more easily when added to food. This study aims to determine the levels of potassium sorbate in jam samples. Potassium sorbate was determined using High Performance Liquid Chromatography (HPLC). From the test results, it was found that potassium sorbate levels ranged from719, $65 \mathrm{mg} / \mathrm{kg}$ to $757,24 \mathrm{mg} / \mathrm{kg}$. The results of this test will be compared with the standards set by the Food and Drug Supervisory Agency (BPOM) No. 36 of 2013 concerning the maximum limit for the use of preservative food additives, namely $500 \mathrm{mg} / \mathrm{kg}$. From the test results, it can be seen that the potassium sorbate in all samples exceeds the quality standard set by the BPOM. Therefore, people must be more careful in choosing jam to consume daily. The test results have used the right method, namely by adjusting the stationary phase, mobile phase and the right wavelength so that the $\%$ recovery results are $103 \%$.
\end{abstract}

\section{PENDAHULUAN}

Selai merupakan salah satu produk makanan yang banyak dikonsumsi masyarakat dan dapat kita jumpai dalam berbagai varian rasa. Di pasaran kita dapat menjumpai selai dengan bahan dasar kacang dan buah yang berfungsi untuk menambah cita rasa pada makanan seperti roti. Selai kacang ialah selai yang terbuat dari bahan dasar kacang tanah yang telah disangrai dan dihaluskan dengan tambahan gula dan garam. Selai buah merupakan salah satu produk pengawet yang memiliki tekstur lunak yang mengandung buah yang telah dihancurkan dan dicampur dengan gula juga disertai penambahan atau tanpa penambahan air.

Pada proses pembuatan selai buah digunakan buah yang telah dihancurkan, pemanis dan pegawet sehingga perlu diperhatikan buah yang digunakan tidak merupakan campuran beberapa buah busuk, penambahan pemanis buatan dan zat pengawet tidak berlebih, serta tidak menggunakan zat pewarna tekstil untuk mendapatkan produk makanan dengan tampilan warna yang lebih menarik.

Untuk meningkatkan mutu selai agar dapat bersaing dipasaran ditambahkan bahan tambahan makanan [1]. Bahan tambahan makanan yang ditambahkan ke dalam produk makanan baik jenis maupun takarannya harus sesuai dengan peraturan yang telah ditetapkan oleh Badan Pengawas Obat dan Makanan, karena bahan tambahan makanan dapat menyebabkan gangguan kesehatan jika dikonsumsi melebihi standar yang telah ditetapkan. Bahan pengawet berfungsi untuk mencegah kerusakan produk yang pada umumnya ditandai dengan pertumbuhan khamir dan kapang dengan cara menghambat enzim sistem genetika sel dan merusak dinding sel sehingga makanan tidak cepat rusak.

Bahan pengawet yang biasa digunakan pada selai ialah garam sorbat seperti natrium sorbat, kalsium sorbat, kalium sorbat dan garam benzoat beserta turunannya. Kalium sorbat merupakan salah satu senyawa asam sorbat sintetis yang sering digunakan sebagai pengawet. Kalium sorbat secara umum dipakai sebagai pengawet 
karena lebih mudah larut jika ditambahkan pada bahan pangan, serta telah banyak digunakan sebagai pengawet di sediaan farmasi, kosmetik, dan sari buah-buahan. Alasan lain yang menyebabkan penggunaan kaium sorbat lebih sering digunakan adalah karena kalium sorbat efektif bekerja sebagai pengawet makanan dan minuman diatas $\mathrm{pH} 6.5$ tetapi keefektifan ini akan semakin meningkat seiring dengan menurunnya $\mathrm{pH}$. Semakin rendah $\mathrm{pH}$ suatu produk makanan atau minuman, maka akan semakin sedikit kalium sorbat yang dibutuhkan untuk proses pengawetan.

Kalium sorbat dapat dikategorikan sebagai pengawet makanan yang tidak terlalu berbahaya bagi kesehatan karena pada dasarnya kalium sorbat tergolong non toksik sehingga aman untuk dikonsumsi. Namun jika dikonsumsi secara berlebih dapat menimbulkan efek negatif bagi kesehatan tubuh seperti mual, muntah dan rasa tidak nyaman pada perut [2]. Standar kalium sorbat sebagai bahan tambahan pada makanan menurut Badan Pengawas Obat dan Makanan No. 36 Tahun 2013 tentang Batas Maksimum Penggunaan Bahan Tambahan Pangan Pengawet adalah maksimum 500 mg/kg [3].

Setelah dilakukan pengujian pada sampel, agar dapat melihat kecermatan dari pengujian dilakukan penentuan \%recovery, karena pada pengujian juga dilakukan tahapan preparasi sehingga untuk memastikan tidak ada penambahan analit karena kontaminasi atau hilangnya analit. Dengan demikian \%recovery menunjukkan kedekatan hasil analisis dengan hasil sebenarnya.

Untuk melakukan pengujian kalium sorbat dan penentuan \%recovery dapat digunakan High Performance Liquid Chromatography (HPLC) yang merupakan alat instrumen jenis kromtografi. Pada proses pemisahannya didasarkan pada distribusi dua senyawa atau lebih diantara dua fasa yaitu fasa diam dan fasa gerak.

Oleh karena itu peneliti tertarik untuk melakukan penelitian ini yang bertujuan untuk mengetahui kadar kalium sorbat pada sampel selai dan mengetahui \%recovery.

\section{METODOLOGI}

Penelitian ini dilakukan di laboratorium kimia makanan dan minuman dengan menggunakan High Performance Liquid Chromatography waters acquity system with $2 D$ LC technology for separation, labu ukur bervolume 50 $\mathrm{ml}, 100 \mathrm{ml}$ dan $25 \mathrm{ml}$, neraca analitik, botol semprot, pipet takar $0.5 \mathrm{ml}, 1 \mathrm{ml}, 2 \mathrm{ml}, 5 \mathrm{ml}, 10 \mathrm{ml}$, dan $15 \mathrm{ml}$, corong kaca, gelas piala $250 \mathrm{ml}$. Untuk mendukung penelitian ini, peneliti juga menggunakan beberapa pereaksi seperti, kalium sorbat sebagai standar dan fasa gerak yang terdiri dari ammonuim asetat, asetonitril, asam asetat.

\section{Penentuan Kadar Kalium Sorbat}

Timbang 4 gram sampel lalu dilarutkan dengan fasa gerak ke labu $50 \mathrm{ml}$. Jika sukar larut panaskan di waterbath. Kemudian diukur kadar K- Sorbat dengan HPLC dengan kolom $\mu$-bondapak C-18, panjang gelombang $254 \mathrm{~nm}$, dan detektor PDA (Photodiodearray).

\section{Penentuan \%recovery}

Pada penentuan \%recovery dilakukan dengan penambahan $10 \mathrm{ml}$ larutan standar ke dalam sampel Setelah itu, sampel yang telah ditambahkan larutan standar disuntikkan ke dalam alat HPLC lalu dihitung konsentrasi perolehan kembalinya.

\section{HASIL DAN PEMBAHASAN}

Hasil penelitian yang telah dilakukan terhadap penentuan kadar kalium sorbat pada sampel selai dapat diamati pada Tabel 1.

Tabel 1. Data Hasil Pengujian

\begin{tabular}{cccc}
\hline No & $\begin{array}{l}\text { Kode } \\
\text { Sampel }\end{array}$ & $\begin{array}{c}\text { Hasil } \\
(\mathrm{mg} / \mathrm{kg})\end{array}$ & $\begin{array}{c}\text { Batas Maksimum } \\
\text { BPOM }(\mathrm{mg} / \mathrm{kg})\end{array}$ \\
\hline 1 & $1020 / 1$ & 757.24 & \\
2 & $1020 / 3$ & 723.67 & 500 \\
3 & $1020 / 5$ & 742.29 & \\
4 & $1020 / 8$ & 731.01 & \\
5 & $1020 / 13$ & 719.65 & \\
\hline
\end{tabular}

Pada Tabel 1 dapat dilihat hasil pengukuran sampel dengan kadar Kalium Sorbat yang didapat berkisar antara 719, $65 \mathrm{mg} / \mathrm{kg}$ hingga 757,24 mg/kg.

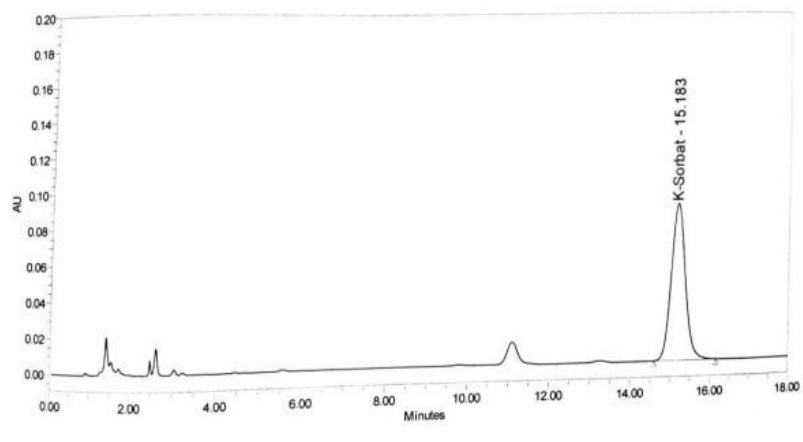

Gambar 1. Kromatogram Sampel Penentuan Kadar Kalium Sorbat

Berdasarkan hasil analisa yang diperoleh maka dapat diketahui penggunaan bahan pengawet kalium sorbat dalam semua sampel selai tidak sesuai dengan standar Badan Pengawas Obat dan Makanan nomor 36 tahun 
2013 tentang bahan tambahan makanan yang mengijinkan penambahan kalium sorbat pada batasan maksimum sebesar $500 \mathrm{mg} / \mathrm{kg}$ [3]. Dengan demikian sampel yang diuji tidak baik dikonsumsi karena penggunaan kalium sorbat yang berlebihan dapat berdampak buruk bagi kesehatan tubuh seperti mual, muntah dan rasa tidak nyaman pada perut [2]. Penggunaan kalium sorbat berlebih dapat diketahui dari aftertaste pahit dan dirasakan juga adanya sensasi coating di lidah [4].

Pada pengujian kalium sorbat dengan menggunakan HPLC dilakukan pengujian \%recovery yang berfungsi untuk menunjukkan kedekatan hasil analisis dengan kadar analit yang sebenarnya untuk melihat keandalan metode yang digunakan. Hasil analisa dapat dilihat pada Gambar 2

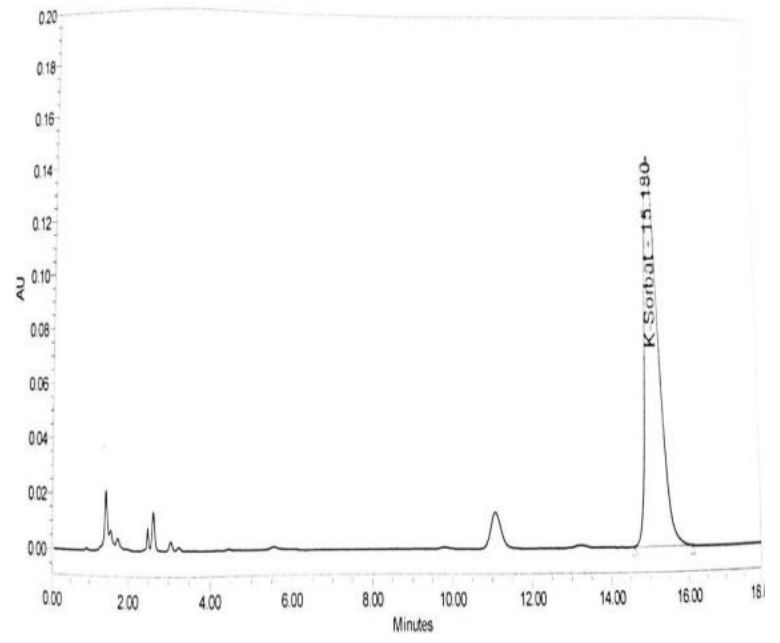

Gambar 2. Kromatogram Pengujian \%recovery

Dari hasil pengujian didapatkan hasil \%recovery sebesar $103 \%$ dimana syarat untuk uji perolehan kembali adalah 90\%-110\%. Dengan demikian metoda yang digunakan pada pengujian sampel selai ini sudah tepat. Waktu elusi bahan pengawet kalium sorbat dipengaruhi oleh $\mathrm{pH}$ dari fase gerak yang cukup asam serta komposisinya yang cukup besar dibandingkan dengan komposisi pelarut organik yang digunakan. Sifat fasa gerak yang cukup asam cenderung menekan atau menghambat ionisasi analit dalam kolom C18.

Adanya gugus silanol (Si-OH) sebagai fasa diam yang polar dan asam mengakibatkan bahan pengawet berinteraksi dan tertahan dalam kolom C18. Kuat atau lemahnya interaksi fasa diam dengan analit didalam kolom dapat diatur dengan mengontrol beberapa parameter seperti $\mathrm{pH}$ fasa gerak dan komposisi antara buffer dengan pelarut organik yang digunakan [6]. Bentuk atau struktur molekul analit juga mempengaruhi retensi bahan pengawet dalam kolom. Secara umum analit dengan dengan luas permukaan hidrofob yang lebih besar seperti C-H, C-C dan ikatan non polar lainnya seperti S-S akan menghasilkan retensi yang lebih lama karena ikatan-ikatan non polar tersebut menurunkan derajat kepolaran pada permukaan analit sehingga semakin meminimalkan interaksinya dengan struktur air yang terkandung dalam fasa gerak. Sebaliknya gugus - gugus polar seperti - $\mathrm{OH},-\mathrm{NH}_{2}, \mathrm{COO}$ dan $\mathrm{NH}_{3}{ }^{+}$dapat mengurangi retensi pada fasa diam karena gugus - gugus polar tersebut berinteraksi dengan baik dengan fasa gerak [5]. Berdasarkan struktur maka kalium sorbat berinteraksi cukup kuat dengan fasa diam sehingga retensinya semakin besar didalam kolom C18.

Dengan penggunaan metode di atas yaitu dengan mengatur fasa gerak, fasa diam dan panjang gelombang yang tepat dapat menghasilkan \%recovery yang baik. Oleh karena itu metode tersebut tepat digunakan untuk pengujian kalium sorbat pada sampel selai.

\section{KESIMPULAN}

Berdasarkan penelitian yang dilakukan didapatkan kadar kalium sorbat pada sampel selai berkisar antara $719,65 \mathrm{mg} / \mathrm{kg}$ hingga 757,24 mg/kg, sehingga kadar kalium sorbat pada sampel tersebut melebihi baku mutu yang ditetapkan oleh BPOM. Pada penelitian juga dilakukan penambahan standar pada sampel sehinnga didapatkan \%recovery $103 \%$.

\section{DAFTAR PUSTAKA}

[1] Dewi, A. Analisis Bahan Pengawet Benzoat secara Titrimetri pada Saos Tomat yang Beredar di Wilayah Kota Pekanbaru. Skripsi. Pekanbaru: Fakultas Tarbiyah dan Keguruan, Universitas Islam Negeri Sultan Syarif Kasim Riau. 2011.

[2] Mugi, Wilujeng. Inilah Batas Maksimum Pengawet dalam Suplemen Kesehatan. Tersedia dari (https://www.medicalogy.com).

[3] Badan POM RI. Peraturan Kepala Badan POM RI No. 36 Tahun 2013 Tentang Batas Maksimum Penggunaan Bahan Tambahan Pangan Pengawet. Jakarta: Badan POM RI. 2013.

[4] Sari, Maya Puspita. Mempelajari Pengaruh Penambahan Bahan Pengawet dan Perlakuan Panas Terhadap Mutu Minuman Kopi dalam Kemasan Cup di PT Garudafood. Skripsi. Fakultas Teknologi Pertanian. Institut Pertanian Bogor. Bogor. 2007.

[5] Merry. Optimasi PH, Komposisi serta Laju Air Fasa Gerak pada Penentuan Kadar Natrium Benzoat dan Kalium Sorbat dalam Bahan Makanan dengan Teknik HPLC. Skripsi. Fakultas Matematika dan Ilmu Pengetahuan Alam. Universitas Indonesia: Depok. 2012. 
[6] Suprianto. Pengembangan Metode Penetapan Kadar Campuran Pemanis, Pengawet dan Pewarna Secara Simultan dalam Sirup Esens dengan Menggunakan Kromatografi Cair Kinerja Tinggi. Tesis. Fakultas Farmasi. Universitas Sumatera Utara: Medan. 2014. 